\title{
A CONSTRUCTIVIST APPROACH TO STUDYING THE BULLWHIP EFFECT BY SIMULATING THE SUPPLY
}

\section{CHAIN}

\author{
Pilar L. González-Torre, B. Adenso-Díaz \& Plácido Moreno
}

European Journal of Engineering Education, 2015

Vol. 40, No. 6, 623-637, http://dx.doi.org/10.1080/03043797.2014.1001816

\begin{abstract}
The Cider Game is a simulator for a supply chain-related learning environment.Its main feature is that it provides support to students in the constructivist discovery process when learning how to make logistics decisions, at the same time as noting the occurrence of the bullwhip phenomenon. This learning environment seeks a balance between direct instruction in the learning process on the part of the tutor, and a suitable and sufficient degree of freedom to regulate independent learning on the part of students.This article describes the basic learning mechanisms usingthe Cider Game and the graphical learning environments that it provides.We describe the functionality provided by this application, and analyzethe effect over the rational understanding of the bullwhip phenomenon by the students and whether they are able to make decisions to minimize its impact, studying the differences when that decision making learning is doneindividually or ingroups.
\end{abstract}

\section{Keywords}

Simulation,supply chain, bullwhip effect, learning/teaching process 


\section{INTRODUCTION}

In university education systems, the process of teaching and learning is largely characterized by the lecture, in which the lecturer explains the rules and principles of a particular topic or concept to students (de Jong et al., 1998). However, the conviction exists that this traditional mode of expository teaching is not the most appropriate means for training students of specific subjects, who needin-depth knowledge that is also flexible and transferable (Coterill, 2013).This need has lead to new educational philosophies in which constructivism plays a key role.In this philosophical approach, students construct their own knowledge based on personal experiences (Woolfolk, 1993; Fosnot, 1996; Kabapinar, 2005; Koohong et al., 2009), that is, their own initiative (Liu \& Zhang, 2014). So the learning process is based on the transfer of a major degree of responsibility from teacher to student.

Constructivism has recently gained popularity, although it is not a completely new learning paradigm (Lainema, 2009). This constructivist learning approach emerged in the last two decades of the $20^{\text {th }}$ century (Applefield et al., 2000-2001) and is characterized by three primary propositions (Savery \& Duffy, 1995): 1) Understanding is in our interactions with the environment; 2) Cognitive conflict is the stimulus for learning and determines the organization and nature of what is learned; 3) Knowledge evolves through the evaluation of the viability of individual understandings.

Constructivism provides a theoretical approach to the use of computer-based systems (Lainema, 2009), encouraging learning through discovery and allowing students to experiment and build their knowledge as "scientists" (Van Joolingen \& de Jong, 1997; Moos and Azevedo, 2009). However, previous experience and studies show that 
students are not always able to manage their own learning process. Van Joolingen \& de Jong (1997) review a number of studies that have shown a wide variety of problems that students may encounter in the learning-through-discovery process.

As mentioned, the use of computer-based learning tools results a natural way of applying this paradigm (Chen, 2003). Over past few decades technological developments have made digital game devices more affordable, and game-assisted learning has become one of the most important approaches for assisted instruction $(\mathrm{Wu}$ et al., 2012). Although most students are skilled users ofinformation and communication technologies outside of school, most of them currently are not doing so inside of school in ways that they find meaningful and relevant to their lives (Campbell et al., 2010). In fact, empirical research has demonstrated that some students have difficulty learning in computer-based environments (Azevedo et al., 2004; Quintana et al., 2005; Moos \&Azevedo, 2009).

Gaming simulations correspond closely to a systemic-constructivist approach to learning (Kriv, 2010) and they constitute a suitable alternative to understanding theory (Deshpande\& Huang, 2011; De Giusti et al., 2008; Chen, 2003). Simulation games refer to instruction delivered via personal computer that immerses trainees in a decisionmaking exercise in an artificial environment in order to learn the consequences of their decisions (Sitzmann, 2011). Computer-assisted learning is a form of simulation-based training (Vogel-Walcutt et al., 2011), that fits perfectly well into this constructivist learning approach.Therefore it seems normal that there are many previous researches that employ a computer teaching system as a constructivist approach: Gold (2001), Pear 
and Crone-Todd (2002), Lainema and Makkonen (2003), Lainema (2009), and Campbell et al. (2010) are some examples.

The use of simulation in business schools started in the 1950s and has grown exponentially since then. Nowadays universities and organizations are investing in computer-based simulation games to train students and employees (Summers, 2004; Bell et al., 2008). In contrast with games (where students use their knowledge to advance in the exercise and win), simulators create evolving situations with many interacting variables, giving the students a role, and addressing issues, threats, and problems, taking decisions and observing their effects (Gredler, 2004). The merits of simulation in education versus other learning alternatives have been objects of controversy. According to Faria and Wellington (2005), business simulators were found to be more effective, from a final examination perspective, than other conventional instructional methods.

In the context of constructivism, this research aims to corroborate that simulation is an adequate teaching tool in the complexity of reverse logistics interrelationships, studying the effects on the individual or group learning. We want to test that the students are able to understand what the bullwhip phenomenon means, so they are able to make decisions (playing as if they are the inventory managers of a company) that reduce the negative effect of the bullwhip. For that purpose a simulator is developed and applied in a realeducational environment.

\subsection{The Bullwhip Effect}


One of the core subjects in Industrial Engineering degrees all over the world is the study of Supply Chain Management.Its intrinsic complexity makes the aforementioned type of constructivist teaching/learning approach highly suitableto study how thesupply chain behaves.

When studying how the supply chain functions, it is seen that decisions have to be made at all times in each of the links comprising the chain, regarding how and when to place an order with the respective supplier.Any error in these decisions can lead to significant additional costs for the company.Orders for less than the required amount will lead to the problem of stock shortages (even compromising the activity of customers downstream), while the opposite case will result in surplus stock (with the ensuing stock maintenance costs in the warehouse that this entails).

One of the possible causes of the appearance of these additional costs is known as the "bullwhip effect". This "phenomenon" refers to variations in demands from their origin at the consumer level all along the supply chain (Chen et al., 2000). As one moves upstream in the supply chain (from customers to raw materials suppliers via all the intermediate links), an increase in the size of orders is produced (Figure 1) due to distortion of information on customer demand between orders from the supplier and consumer sales (Bayraktar et al., 2008). This fact can misguide upstream members in their inventory and production decisions (Lee et al. 1997).

$=======$ Figure 1 =ニ=ニ=ニ=ニ= 
This demand is magnified when transformed by the different links through orders to those upstream in the supply chain (Chen et al., 2000) and may even cause instability and lead to increases in the cost of the product.This phenomenon occurs because of the existing uncertainty in each link in the chain when estimating its demand, thereby leading to increased variability in demand.Consequently, the study of this phenomenon is widespread in all universities where Operations Management is taught.

Research on the bullwhip effect can be divided into two periods:the period between 1997 and 2000, constituting the stage of rediscovery of the bullwhip effect, during which the aim was to prove its existence and possible causes; and from 2000 on, when research has focused on how to avoid this effect (Holweg \& Disney, 2005).

\subsection{Simulation of the supply chain}

Given the interaction among many decision makers periodically launching orders, simulation was soon seen as an appropriate tool to try to understand that phenomenon.

A software application or game developed by MIT in the 1960s called the Beer Game has traditionally been used to study the functioning of the supply chain and the bullwhip effect (Sterman, 1989).It consists of a simulation of a production and distribution system made up of a simple beer supply chain involving four links:(1) factory, (2) distributor, (3) wholesaler, and (4) retailer.

The managers of each of these links place orders and manage the stocks in their own facilities.The decisions of each of the four links can be made by a decision maker or player (for example, a student) or by the computer, depending on the purpose of each 
simulation.In each period, the respective managers of the retailer link, wholesaler and bottler observe the external demand. They try to fulfilthis demand as soon as possible, recording backorders and placing the necessary orders with the upstream actor.The necessary production decisions are taken in the factory on the basis of the same information received by the distributor, once his demand has been met.

Since the Beer Game was first introduced, new simulators have been developed with different features, elements and degrees of interactivity (Table 1).

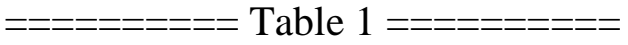

One of the best known options is the "MIT Beer Game" (http://beergame.mit.edu/), developed by Michael Li and David Simchi-Levi, and belonging to the MIT Forum for Supply Chain Innovation.Version 3.0, which was introduced in November 2005, is considered the basic reference for electronic versions of the Beer Game.It is possibly the most widely used simulator for a number of reasons: it was the first application available, has the MIT seal (creators of the original Beer Game) and offers the possibility to log on to games created on any computer.

The Scandinavian company MA-System, which specializes in supply chain management, developed the "MA-System Beer Game" (http://www.masystem.com/o.o.i.s/1365).Its main feature is its intuitive user-friendly design, with few options to choose from, but still very easy to use. 
In 2007, Kai Riemer, from the University of Munster, presented the "Beer Game Portal" (http://www.beergame.org).This free application is only available for educational purposes after prior contact with its creator.Offering an attractive interface, it has numerous configurable options and is one of the most comprehensive options to date.

The "Beer Distribution Game" (http://www.beergame.lim.ethz.ch/) was devised by Jörg Nienhaus, from the Zurich Institute of Technology, and was implemented by Christoph Duijts in 2002. Its interface is now somewhat dated and it is not very user-friendly.It is available in both English and German.

Another available simulator is the "Updated Beer Game" (http://davinci.tamu.edu/beergame/v1/), the first version of which was released in 2005 by a researcher at the University of Texas. The underlying idea was to provide a version of the Beer Game with more configuration possibilities and options.

In 2008, Forio Online Simulations developed the "Root Beer Game" (http://forio.com/sim-store/demos/root-beer-game.html) in collaboration with HarvardBusinessSchool.A subscription fee is charged per user to $\log$ on to the application, with a reduced fee if used for academic purposes.Although the number of configuration options is limited, its design has a professional-looking appearance with animations.

Despite their different features, there is one aspect that none of these simulators covers:none contemplates the simulation of closing the supply chain loop, allowing returns of material once used by the customer, which is currently a hot research topic 
(reverse logistics paradigm; see Prahinski\& Kocabasoglu, 2006). Therefore, it has been necessary to develop new software that addressesthe teaching of this subject matter in a more practical way, including the use of recycled material. The developed software allows students to make decisions as members of the supply chain in a highly flexible way and in a fully configurable environment.

\section{DESCRIPTION OF THE CIDER GAME}

The Cider Game (see Adenso-Díaz et al., 2012) is a simulator for a supply chain whose most significant feature is to include reverse logistics decisions. It has been developed primarily to help students understand the bullwhip effect, as its main design principle is to allow a complete parameterization of the simulation. Since supply chains are so dynamic and can be very different from one another, we consider parameterization (i.e., the ability to decide about costs, delays, the information to be published to the players, the capacities, the way the automatic mode will make calculations and recommendations, the safety stock, the backlog decisions, etc.) should be distinctive of this software.

This new learning tool simulates a supply chain with product returns, inspired by the cider supply chain (by analogy with the classic beer supply chain) where bottles are returned after use.The traditional supply chain begins with the providers of raw materials and finishes with the purchase by or distribution of goods to the end customer (La Londe \& Masters, 1994; Beamon, 1998; Cardoso et al., 2013; Danese, 2013). Specifically the supply chain considered in this paper is composed of six links (Figure 2): (1) raw materials supplier, (2) cider factory, (3) bottler, (4) wholesaler, (5) retailer, and (6) end customer.In addition, once the product has been consumed, the end 
customer has two choices regarding what to do with the empty bottle:(i) send it to landfill (when the end product has no value, it is directly discharged due to the end of its useful life), or (ii) return it to the recycler (when the same value can be recovered from the end bottle, this is the better environmentally-friendly challenge). Reverse logistics (Cardoso et al., 2013; González-Torre et al., 2010; González-Torre \&Díaz-Fernández, 2006) is therefore considered in the supply chain simulated.

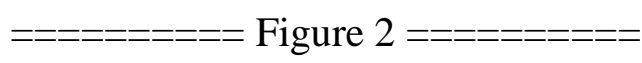

The Cider Game takes the form of a client-server application. The server manages the connection with users/clients, sets the values of the parameters, and manages and monitors the status of the simulation.It also processes all the logistics of the supply chain and calculates the orders from the different links.

In the clients'part, the players log on to a certain link in the chain anddecide on the orders to place with their respective suppliersin each iteration of the simulation, with the goal of satisfying demand and reducing costs.

\subsection{Man-machine interface}

The main screen of the server is shown in Figure 3.

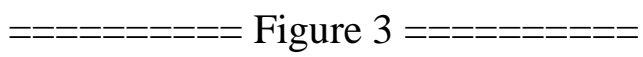

This screen can be broken down into five parts: 
- Server data, indicating the server's IP address. This information will be needed to enable each client to $\log$ on. The importance of using remote simulation was identified by Balamuralithara and Woods (2009).

- Weeks, which enables the number of weeks to simulate to be specified, as well as the number of weeks of warm-up, so that the application does not start the simulation from an unrealistic situation with all fields at zero.

- Information about other actors, where the information available to the different links on the actual demand of end customers through their downstream link can be defined (information sharing).By default, each link can only provide information about itself.

- Automatic/Manualsimulation,used to indicate the type of simulation. In the former case, all the links are managed by the server; in the latter, players are allowed to participate by making decisions in the different links.

- Supply chain, which defines different configurations of the supply chain:return supply (enables the option to return material to the chain), backlog links (indicates whether stockouts are served late or not), raw materials production limited (sets the supply capacity of raw materials to the factory, which by default is assumed to be unlimited).

As stated, this program is fully reconfigurable. At the bottom of this screen is theServer Parameters button, which brings up a new screen (Figure 4) in which all the parameters of the game can be set. The parameters are grouped into six different areas:

- Demand generation for the end customer using different patterns (uniform, normal or empirical distribution).

- Stock data for each link (value of initial stock and desired safety stock). 
- Return chain, where stock characteristics can be defined as well as the percentage of bottles (with respect to the total amount reaching the customer) to be recycled (the rest go to landfill), maximum stock capacity of recycled bottles (the rest go to landfill), and maximum number of bottles the recycler can receive and process in each period (the rest remain pending future orders).In turn, the bottler can split orders two ways:to the factory (unused material) or to the recycler.

- Costs (holding and backorder), needed to assess the effectiveness of the stock policy followed by each actor.

- Raw material, where the production ceiling of the link that provides the raw material is determined, when choosingto limit this amounton the main screen.

- Automatic order calculation: In each period, participantsmust make a decision regarding the amount of the order to be sent to their respective suppliers which will depend on their received demand and other available information. The program makes the decision in automatic mode, while in manual mode it makes suggestions to the user following the specified guidelines for this parameter. The first four rows refer to the model for forecastingdemand in previous periods, which may be moving average or exponential smoothing. The next four rows comprise the parameters for calculating orders and the initial forecast for each link (field PREV1). In the case of automatic ordering, the alternative provided by the program in each link can be modified using the batch settings found in the last five rows: $\mathrm{NN}$ (do not modify the calculation), Q (order of a certain quantity, only modify when the calculation for the order is zero or less than Q), Qmin (smallestbatch permitted). 
There are a number of buttons at the bottom of this parameter screen which fulfil the following functions:Return (closes the settings screen after updating the value that appears in thescreen), Cancel (closes the screen without making any entered changes), Reset (resets to the default settings), and Go to Delays (opens the screen for assigning values to delays, both in the flow of materials and in information).

Having defined the parameters, the players of the different links can then log on and the simulation can commence by clicking on the Run button in the main screen of the server.

In the manual simulation, after each link has made the appropriate decisions in each time period, the Go button has to be clicked on the server to begin the process of decision-making for the next period.

The information available to the player at each link for decision-making is as follows (Figure 5):

- IO: input order from previous link at start of period t.

- IS: input shipment from supplier at start of period t.

- OS: output shipment sent to previous linkin the middle of period $t$, considering orders and backlog.

- INV: stock at the end of period t.

- BL: backlog at the end of period t.

- $\mathrm{OO}_{\mathrm{t}-1}$ : output order made to the supplier in the previous period. 
- $\operatorname{COST}_{\mathrm{t}-1}$ : accumulated cost at the end of period $\mathrm{t}-1$.

- $\mathrm{OO}_{\mathrm{t}}$ : order made to the supplier (as a manual or an automatic decision).

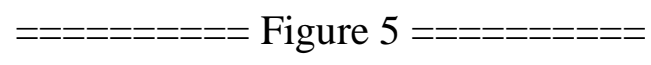

In each period, incoming materials and orders are received, the material is shipped to the downstream link, stock and backlogs are updated, and the order to place with the supplier is determined.

Once the entire simulation process has been completed, the Results screen displays all the results obtained (Figure 6). Moreover, the application allows all the data from the simulation to be exported period-by-period to a file for possible further treatment.

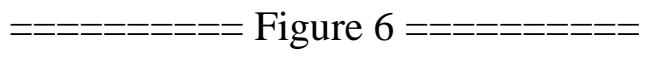

\subsection{Use in the classroom}

Table 2 presents a description of the main features of the Cider Game, showing the main contributions of the application described in this research study.

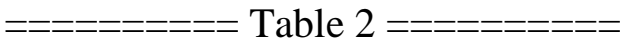

One way to setup the learning process using the tool is the following: in the classroom the tutor can divide the class into groups of students, one for each link in the chain, and then direct the entire simulation process from his post (server); i.e. a single simulation for the whole class. Alternatively, he can ask studentsto make individual decisions from 
their respective posts after choosing a link and then let the computer make decisions for each of the other links in automatic mode ( $n$ simulations in parallel). Whatever themethod used, the results can be analyzed retrospectively by studying the overall costs incurred as well as stock levels, backlogs and, of course, the observed bullwhip effect.

When a student starts using a system like this one, he/she has to face two main kinds of difficulties: one is related to the use of a new computer tool; the other one is to understand at the same time the complex concepts that are being taught. Any tool of this kind has to try to minimize both learning barriers. In our case we have followed two strategies: first, we opted out to design a fully parameterized system that makes more flexible its use and finally more adapted to the students requests; secondly, it was readapted while being developed to look for a friendlier environment. Our experience when the students learnt using the simulator was that no major problems were discovered while working with Cider Game.

\section{LABORATORY EXPERIMENT}

In spite of the importance of communication for the society development, not much is known about how we integrate other's opinions when making decisions as part of a group (Hastie and Kameda, 2005). Normally the opinions from the other members of a team should have influence on our personal point of view, affecting our outcomes. Not much research was done regarding how collective decisions are affecting learning decision in the scope of simulation software. One example is the medical training software PgWSE, developed in Scotland for observing the performance of trainees (Stirling et al, 2012) where individual and consensus judgments regarding trainee's performance are considered. 
Therefore it was decided to conduct an experiment to assess the results of its use in the classroom and to determine to what extent the simulation results obtained by students depend on their way of working with the software.This is a typical applied case of a constructivist learning approach,as defined byKriv (2010) or Lainema (2009).

It was decided to test whether the fact that decisions regarding the size of the orders are taken in groups or individually can affect the efficiency of the supply chain. The number of students who would make the joint decision at one of the links in the supply chain was considered as a factor in the experiment, with two levels:one single student makes the decision, or the decision is made jointly by a team of two students. This proposition tries to corroborate if the cooperative learning is more efficient than the individual learning. Using the proposed constructivist-tool, students can discuss and clarify their experiences. This fact encourages self-organization and reflective abstraction as is pointed out by Chen (2003).

In the experiment, an intermediate link (the wholesaler) was chosen to be assigned to the student(s) so that the player(s)could make their own decisions, while the rest of the links were controlled automatically by the Cider Game (automatic mode). The experiments were conducted in a graduate class on Logistics Management involving 24 students. They each performed 10 suitably randomized replications of each combination of levels (i.e., they each performed a total of 20 simulations), collecting in each one the measurement of the registered bullwhip effect (by means of the Total Variance Amplification, TVA, defined as the ratio between the variance of demand in any link, and the variance of demand of final consumer, $\frac{\sigma_{\text {output_order_k }}^{2}}{\sigma_{\text {demand }}^{2}}$; see Adenso-Díazet al., 
2012), average stock, and average backlog. Statistical analysis was carried out using $R$ statistical software (Crawley, 2009).

\subsection{Analysis of results}

Table 3 shows the descriptive analysis of the three study variables commented on above.Figure 4 presents a boxplot used to visualize the three variables as a function of the two factor levels considered.



Parametric procedures may be used first to determineif there are differences between the two levels for any variable.However, a study of the normality of the three variables under study allows us to reject the null hypothesis of normality in all cases.For this purpose, we used a non-parametric method, namely the Mann-Whitney U Test (Table 4) to test whether the distributions between two independent groups are the same in the three study variables for each of the two groups into which the sample is divided(Gibbons andChakraborti, 2011). The results given by the software R (see Table 4) reveal significant differences for the three variables $(p \approx 0.0)$, i.e., the simulation results clearly differ, depending on whether the student makes decisions alone or in collaboration with a partner.In view of the results in Table 3, it would seem that ajoint decision made with a classmate gives rise to a lesser bullwhip effect, even though the average stocks are different. 


\section{CONCLUSIONS}

A software application,namely the Cider Game, has been developed to carry out laboratory teaching in Supply Chain Management. Itpresents an improvement on the software available for experimenting with the bullwhip phenomenon, thanks to its great potential due to parameterization.It includes the possibility of incorporating the reverse chain of supply in addition to maintaining the potential of previous simulators.

The paper shows how the use of a simulator game can help to understand a complex concept such as bullwhip. This tool appears to be an important way to easethe difficulties of studying the supply chain, simulatingcomplex environments and allowing the student to test the difficulty of implementing the management of returns in a company in which orders are diversified among several suppliers, and where both unused and reused materials have to be managed.

Furthermore, the application allows the tutor to demonstrate in a constructivist way the difficulty of making decisions in a company when the actual market demand is not known first hand, i.e., when demand is distorted by safety stock and delay times, both in the receiving of information and in the shipping of orders.

This teaching tool was first used at the University of Oviedo in 2011 with great success in terms of the perception of students as game users.Students were really satisfied with the possibility of constructing their own knowledge and immediately seeing the results of their decisions. In addition we found thatlearning differences exist,depending on whether the game is played individually by the student or whether decisions are made as 
a team. The experiment reveals that different decisions are in fact taken in the two cases, resulting in different performance in terms of the registered bullwhip effect, stock and backlog. When students make decisions together, they obtain better solutions due to the cooperative and constructivist learning approach carried out. Finally, we must note that although other commercial tools with the same educational aim also employ a constructivist methodology to teach the management of the supply chain, the Cider Game is unique in dealing with today's hot research topics, such as those related to reverse logistics.

As a further analysis of the software, new experiments should be performed to compare the understanding of the supply chain when the students use the new software and when using any of the previously existing ones. This comparison could give information about the role of designing fully adaptable simulators and their advantages for the learning process. Finally, perhaps the number of decision-makers in the group could make a difference. New experiments could be performed comparing the decision taken according the size of group.

\section{FUNDING}

The research was funded by the Spanish Ministry of Science (grant DPI2013-41469-P) and FEDER.

\section{REFERENCES}

Adenso-Díaz, B.; P. Moreno; E. Gutierrez; S. Lozano (2012): “An analysis of the main factors affecting bullwhip in reverse supply chains", International Journal of Production Economics, vol.135, pp.917-928. 
Applefield, J.M.; R. Huber; M. Moallen (2000-2001): “Constructivism in theory and practices: toward a better understanding", The High School Journal, vol.84, no.2, pp.3553.

Azevedo, R.; J.T. Guthier, D. Seibert (2004): “The role of self-regulated learning in fostering students' conceptual understanding of complex systems with hypermedia", Journal of Educational Computing Research, vol.30, pp.87-111.

Balamuralithara, B.; Woods, P.C. (2009): "Virtual laboratories in engineering education: The simulation lab and remote lab",Computer Applications in Engineering Education, vol.17, no.1, pp.108-118.

Bayraktar, E.; S.C. Lenny Koh; A. Gunasekaran; K. Sari; E. Tatoglu (2008): “The role of forecasting on bullwhip effect for E-SCM applications", International Journal of Production Economics, vol.113, pp.193-204.

Beamon, B. (1998): "Supply chain design and analysis: models and methods", International Journal of Production Economics, vol.55, no.3, pp.281-294.

Bell, B.S.; A.M. Kanar, S.W.J. Kozlowski (2008): “Current issues and future directions in simulation-based training in North America", The International Journal of Human Resources Management, vol.19, pp.1416-1436.

Campbell, T.; S.K. Wang, H.-Y. Hsu, A.H. Duffy, P.G. Wolf (2010): "Learning with Web tools, simulations, and other technologies in science classrooms", Journal of Science Education and Technology, vol.19, no.5, pp.505-511.

Cardoso, S.R.; A.P.F.D. Barbosa-Póvoa, S. Relvas (2013): "Design and planning of supply chains with integration of reverse logistics activities under demand uncertainty", European Journal of Operational Research, vol.226, pp.436-451. 
Chen, C. (2003): "A constructivist approach to teaching: Implications in teaching computer networking", Information Technology, Learning and Performance Journal, vol.21, no.2, pp.17-27.

Chen, F.; Z. Drevner; J.K. Ryan; D. Simchi-Levi (2000): “Quantifying the bullwhip effect in a simple supply chain: the impact of forecasting, lead times, and information", Management Science, vol.46, no.3, pp.436-443.

Coterill, S.T. (2013): “Tearing up the page: re-thinking the development of effective learning environments in higher education"; Innovations in Education and Teaching International, DOI 10.1080/14703297.2013.862174.

Crawley, M. J. (2009):The R Book. Wiley, England.

Danese, P. (2013): "Supplier integration and company performance: A configurational view", Omega, vol.41, pp.1029-1041.

De Giusti, M.R.; Lira, A.J.; Villarreal, G.L. (2008) "Simulation framework for teaching in modeling and simulation areas" European Journal of Engineering Education, vol.33, no.5-6, p.587-596.

De Jong, T.; W.R. van Joolingen; J. Swaak; K. Veermans; R. Limbach (1998): "Combining human and machine expertise for self-directed learning in simulation-based discovery environments", Journal of Computer Assisted Learning, vol.14, no.3, pp.235246.

Deshpande, A.A.; S.H. Huang (2011): "Simulation games in engineering education: A state-of-the-art review", Computer Applications in Engineering Education, vol.19, no.3, pp.399-410.

Faria, A.J., Wellington, W.J. (2005): "Validating business gaming: Business game conformity with PIMS findings", Simulation \& Gaming, vol.36, pp.259-273. 
Fosnot, C.T. (1996): Constructivism: a psychological theory of learning, Teachers College Press, New York.

Gibbons, J.D.; S. Chakraborti (2011) Nonparametric Statistical Inference, Taylor and Francis, Boca Raton, FL.

Gold, S. (2001): "A constructivist approach to online training for online teachers", Journal of Asynchronous Learning Networks, vol.5, no.1, pp.35-57.

González-Torre, P.; M. Alvarez, J. Sarkis, B. Adenso-Díaz (2010): "Barriers to the implementations of environmentally oriented reverse logistics: evidence from the automotive industry sector”, British Journal of Management, vol.21, no.4, pp.889-904.

González Torre, P.L.; A. Díaz Fernández (2006): "Reverse logistics practices in the glass sector in Spain and Belgium”, International Business Review, vol.15, pp.527-546.

Gredler, M.E. (2004): "Games and simulations and their relationship to learning”. In Handbook of Research on Educational Communications and Technology, ed. D.H. Jonassen, pp.571-581. Mahwah, NJ: Lawrence Erlbaum Associates.

Holweg; M.; Disney, S.M. (2005): “The evolving frontiers of the bullwhip problem", EUROMA Conference proceedings, Budapest, Hungary, pp.707-716.

Hastie; R; Kameda, T. (2005): “The robust beauty of majority rules in group decisions", Psychology Review, vol. 112, no. 2, pp. 494-508.

Kabapinar, F. (2005): "Effectiveness of teaching via concept cartoons from the point of view of constructivist approach", Educational Sciences Theory \& Practice, vol.5, no.1, pp.135-146. 
Koohong, A.; L. Riley; T. Smith (2009): "E-learning and constructivism: from theory to application", Interdisciplinary Journal of E-learning and Learning Objects, vol.5, pp.91-109.

Kriv, W.C. (2010): "A systemic-constructivist approach to the facilitation and debriefing of simulations and games", Simulation and Gaming, vol.41, no.5, pp.663680.

La Londe; B.J.; Masters, J.M. (1994): "Supply chain management: myth or reality?",Supply Chain Management Review, vol.1, spring, pp. 6-7.

Lainema, T. (2009): "Perspective making: Constructivism as a meaning-making structure for simulations gaming", Simulation and Gaming, vol.40, no.1, pp.48-67.

Lainema, T.; P. Makkonen (2003): “Applying constructivist approach to educational business games: Case REALGAME”, Simulation \& Gaming, vol.34, pp.131-149.

Lee, H.L.; V. Padmanabhan; S. Whang (1997): "Information distortion in a supply chain: the bullwhip effect", Management Science, vol.43, no.4, pp.546-558.

Liu, L.; Y. Zhang (2014): "The application of constructivism to the teaching of intercultural communication"; English Language Teaching, vol.7, no.5, pp.136-141.

Moos, D.C.; R. Azevedo(2009): “Learning with computer-based learning environments: A literature review of computer self-efficacy", Review of Educational Research, vol.79, no.2, pp.576-600.

Pear, J.J.; D.E. Crone-Todd (2002): "A social constructivist approach to computermediated instruction", Computer \& Education, vol.38, pp.221-231.

Prahinski, C.; C. Kocabasoglu (2006): "Empirical research opportunities in reverse supply chains", Omega, vol.34, no.6, pp.519-532. 
Quintana, C.; M. Zhang, J. Krajcik (2005): “A framework for supporting metacognitive aspects of online inquiry through software-based scaffolding", Educational Psychologist, vol.40, no.4, pp.235-244.

Savery, J.R.; T.M Duffy (1995): “Problem based learning: An instructional model and its constructivist framework", Educational Technology, vol.35, pp.31-38.

Sitzmann, T. (2011): “A meta-analytic examination of the instructional effectiveness of computer-based simulation games", Personnel Psychology, vol.64, pp.489-528.

Sterman, J.D. (1989): "Modeling managerial behavior: Misperceptions of feedback in a dynamic decision making experiment”, Management Science, vol.35, no.3, pp.321-339.

Stirling; K.; Hogg; G.; Ker; J.; Anderson; F.; Hanslip; J.; Byrne; D. (2012): “Using simulation to support doctors in difficulty“", The Clinical Teacher, vol. 9, no. 5, pp. 285289.

Summers, G.J. (2004): “Today’s business simulation industry”, Simulation \& Gaming, vol.35, pp. 208-241.

Van Joolingen, W.R.; De Jong, T. (1997): “An extended dual search space model of learning with computer simulations”, Instructional Science, vol.25, pp.307-346.

Vogel-Walcutt, J.J.; J.B. Gebrim, C. Bowers, T.M. Carper, D. Nicholson(2011): “Cognitive load theory vs. constructivist approaches: Which best leads to efficient, deep learning?", Journal of Computer Assisted Learning, vol.27, no.2, pp.133-145.

Woolfolk, A.E. (1993): Educational Psychology, Allyn and Bacon, Boston.

Wu, W.-H.; W.-B.Chiou; H.-Y.Kao; C.-H. A. Hu; S.H. Huang (2012): "Re-exploring game-assisted learning research: The perspective of learning theoretical cases", Computers \& Education, vol.59, pp.1153-1161. 


\begin{tabular}{|c|c|c|c|c|c|c|c|}
\hline & M-BG & MA-BG & BG-P & BDG & U-BG & R-BG & $\mathbf{C G}$ \\
\hline Number of links (fixed or variable) & 4 & 4 & $3-5$ & 4 & variable & 4 & $5-6$ \\
\hline Return of material (closed loop) & No & No & No & No & No & No & Yes \\
\hline Free software & Yes & Yes & $\begin{array}{l}\text { Yes (in } \\
\text { academia) }\end{array}$ & Yes & $\begin{array}{l}\text { Yes (in } \\
\text { academia) }\end{array}$ & No & Yes \\
\hline Links also controlled by computer & Yes & Yes & No & Yes & No & No & Yes \\
\hline Period of simulation variable & Yes & 52 weeks & Yes & 25 weeks & Yes & Yes & Yes \\
\hline Warm-up & & & No & & No & No & Yes \\
\hline Supply delays & $\begin{array}{l}1 \text { or } 2 \\
\text { weeks }\end{array}$ & 2 weeks & $1-3$ weeks & 2 weeks & $1-2$ weeks & $1-2$ weeks & 1-9 weeks \\
\hline Order delays (fixed or variable) & 1 week & 2 weeks & 1 week & 1 week & $0-2$ weeks & 1-2 weeks & 1-9 weeks \\
\hline $\begin{array}{l}\text { Shared information: } \\
\text { ○ stocks } \\
\circ \text { backlogs } \\
\circ \text { material sent } \\
\circ \text { orders } \\
\circ \text { demand }\end{array}$ & $\begin{array}{l}\text { Yes } \\
\text { Yes } \\
\text { Yes }\end{array}$ & & $\begin{array}{l}\text { Yes } \\
\text { Yes }\end{array}$ & $\begin{array}{l}\text { No } \\
\text { No } \\
\text { No } \\
\text { No } \\
\text { No }\end{array}$ & $\begin{array}{l}\text { Yes } \\
\text { Yes }\end{array}$ & Yes & $\begin{array}{l}\text { Yes } \\
\text { Yes } \\
\text { Yes } \\
\text { Yes } \\
\text { Yes }\end{array}$ \\
\hline Holding cost and backlog cost variable & No & No & No & No & Yes & No & Yes \\
\hline Backlog/no backlog option & No & No & No & No & No & No & Yes \\
\hline $\begin{array}{l}\text { Possible limitation of production } \\
\text { capacity }\end{array}$ & No & No & & & & & Yes \\
\hline Demand generation as a parameter & Automatic & Automatic & & $U[4,8]$ & Yes & & Yes \\
\hline Different order policies & No & No & & & & & Yes \\
\hline $\begin{array}{l}\text { Screen data information: } \\
\text { ○ stocks } \\
\circ \text { backlog } \\
\circ \text { order from customer } \\
\circ \text { material sent to client } \\
\circ \text { material received } \\
\circ \text { order to supplier } \\
\circ \text { previous order to supplier } \\
\circ \text { work in process material } \\
\circ \text { supplier backlog } \\
\circ \text { accumulated costs } \\
\end{array}$ & $\begin{array}{l}\text { Yes } \\
\text { Yes } \\
\text { Yes } \\
\text { Yes } \\
\text { Yes } \\
\text { Yes } \\
\text { Yes } \\
\text { Yes } \\
\text { Yes } \\
\text { Yes }\end{array}$ & $\begin{array}{l}\text { Yes } \\
\text { Yes } \\
\text { Yes } \\
\text { Yes } \\
\text { Yes } \\
\text { Yes } \\
\text { No } \\
\text { No } \\
\text { No } \\
\text { Yes }\end{array}$ & $\begin{array}{l}\text { Yes } \\
\text { Yes } \\
\text { Yes } \\
\text { Yes } \\
\text { Yes } \\
\text { Yes } \\
\text { No } \\
\text { No } \\
\text { No } \\
\text { Yes }\end{array}$ & $\begin{array}{l}\text { Yes } \\
\text { Yes } \\
\text { Yes } \\
\text { No } \\
\text { Yes } \\
\text { Yes } \\
\text { Yes } \\
\text { Yes } \\
\text { Yes } \\
\text { Yes }\end{array}$ & $\begin{array}{l}\text { Yes } \\
\text { Yes } \\
\text { Yes } \\
\text { Yes } \\
\text { Yes } \\
\text { Yes } \\
\text { No } \\
\text { No } \\
\text { No } \\
\text { Yes }\end{array}$ & $\begin{array}{l}\text { Yes } \\
\text { Yes } \\
\text { Yes } \\
\text { Yes } \\
\text { Yes } \\
\text { Yes } \\
\text { No } \\
\text { No } \\
\text { No } \\
\text { Yes }\end{array}$ & $\begin{array}{l}\text { Yes } \\
\text { Yes } \\
\text { Yes } \\
\text { Yes } \\
\text { Yes } \\
\text { Yes } \\
\text { Yes } \\
\text { Yes } \\
\text { Yes } \\
\text { Yes }\end{array}$ \\
\hline $\begin{array}{l}\text { Results report /graphical output: } \\
\text { ○ stocks } \\
\text { ○ backlog } \\
\circ \text { orders } \\
\circ \text { costs } \\
\circ \text { can be exported } \\
\end{array}$ & $\begin{array}{l}\text { Yes } \\
\text { Yes } \\
\text { Yes } \\
\text { Yes } \\
\text { Yes }\end{array}$ & $\begin{array}{l}\text { Yes } \\
\text { No } \\
\text { Yes } \\
\text { Yes }\end{array}$ & $\begin{array}{l}\text { No } \\
\text { No } \\
\text { Yes } \\
\text { No } \\
\text { Yes }\end{array}$ & $\begin{array}{l}\text { Yes } \\
\text { No } \\
\text { Yes } \\
\text { Yes }\end{array}$ & $\begin{array}{l}\text { Yes } \\
\text { No } \\
\text { Yes } \\
\text { Yes }\end{array}$ & $\begin{array}{l}\text { Yes } \\
\text { No } \\
\text { Yes } \\
\text { Yes }\end{array}$ & $\begin{array}{l}\text { Yes } \\
\text { Yes } \\
\text { Yes } \\
\text { Yes } \\
\text { Yes }\end{array}$ \\
\hline
\end{tabular}

Table 1. Characteristics of different simulators of the bullwhip effect.

(Note: M-BG:MIT Beer Game; MA-BG:MA-System Beer Game; BG-P: Beer Game Portal; BDG: Beer Distribution Game; U-BG:Updated Beer Game; R-BG:Root Beer Game; CD: Cider Game) 


\begin{tabular}{|c|c|c|c|}
\hline BASIC DATA & PARAMETERS & $\begin{array}{l}\text { SCREEN } \\
\text { INTERFACE }\end{array}$ & $\begin{array}{l}\text { EXTRA } \\
\text { FEATURES }\end{array}$ \\
\hline $\begin{array}{l}\text { - Published in } 2011 . \\
\text { - } 4 \text { coe. } \\
\text { (factory, distributor, } \\
\text { wholesaler and retailer). } \\
\text { - The links can be } \\
\text { controlled by the } \\
\text { program. } \\
\text { - The server provides an IP } \\
\text { address for the clients to } \\
\text { log on. } \\
\text { - Closed loop: a recycling } \\
\text { stage can be added aimed } \\
\text { at incorporating } \\
\text { containers returned by } \\
\text { the customer. } \\
\text { - The possibility of a } \\
\text { warm-up exists: the } \\
\text { initial values of the } \\
\text { simulation are the end } \\
\text { values of the warm-up. } \\
\text { - The possibility of } \\
\text { automatic simulation } \\
\text { exists: step-by-step or } \\
\text { directly to the final } \\
\text { results. }\end{array}$ & $\begin{array}{l}\text { - Backlogs can be } \\
\text { considered or not. } \\
\text { - Weeks of simulation. } \\
\text { - Shared information (it is } \\
\text { possible to determine } \\
\text { which variables from } \\
\text { each of the other links } \\
\text { can be seen for each } \\
\text { link). } \\
\text { - Storage and unserved } \\
\text { demand costs. } \\
\text { - Delays in orders and } \\
\text { deliveries are } \\
\text { configurable (from } 1 \text { to } \\
10 \text { periods). The } \\
\text { possibility of adding } \\
\text { randomness also exists. } \\
\text { - Value of the production } \\
\text { capacity (fixed or } \\
\text { unlimited). } \\
\text { - End customer demand: } \\
\text { uniform, normal or } \\
\text { empirical. Demand trend. } \\
\text { - Initial stock values. } \\
\text { - Automatic calculation of } \\
\text { orders: parameters for } \\
\text { calculating demand } \\
\text { forecast, stock } \\
\text { adjustments and work in } \\
\text { progress. } \\
\text { - Batch orders. } \\
\text { - Percentage of recycled } \\
\text { containers. } \\
\text { - Capacity of the recycler. } \\
\text { - Safety stock. }\end{array}$ & $\begin{array}{l}\text { - Stock and backlog. } \\
\text { - Customer order. } \\
\text { - Material received. } \\
\text { - Material sent to the } \\
\text { customer. } \\
\text { - Previous order to the } \\
\text { supplier. } \\
\text { - Material in the course of } \\
\text { completion (to within } 5 \\
\text { periods). } \\
\text { - Accrued costs. } \\
\text { - A suggestion is made } \\
\text { regarding the amount to } \\
\text { order. } \\
\text { - Demand forecast, stock } \\
\text { adjustments and work in } \\
\text { progress (WIP) are } \\
\text { shown. } \\
\text { - If enabled, the } \\
\text { parameters for } \\
\text { calculating the orders } \\
\text { made by the server can } \\
\text { be modified. }\end{array}$ & $\begin{array}{l}\text { - The administrator can } \\
\text { monitor the progress of } \\
\text { all players. } \\
\text { - Parameter settings can be } \\
\text { saved and previous } \\
\text { parameter settings can be } \\
\text { imported. } \\
\text { - Results can be saved and } \\
\text { exported, and previous } \\
\text { results can be loaded. } \\
\text { - Order graph and a } \\
\text { summary of statistics and } \\
\text { indicators available at the } \\
\text { end of the simulation. }\end{array}$ \\
\hline
\end{tabular}

Table 2. Cider Game Features 


\begin{tabular}{|l|c|c|}
\cline { 2 - 3 } \multicolumn{1}{c|}{} & \multicolumn{2}{c|}{ Factor 1 } \\
\cline { 2 - 3 } & 1 & 2 \\
\cline { 2 - 3 } \multicolumn{1}{c|}{} & 6.43 & 3.17 \\
& $(6.47)$ & $(3.15)$ \\
\hline TVA & 48.59 & 100.35 \\
& $(77.95)$ & $(49.31)$ \\
\hline Average backlog & 0.76 & 7.15 \\
& $(3.04)$ & $(14.21)$ \\
\hline
\end{tabular}

Table 3. Descriptive analysis (average and standard deviation in parentheses) of the 3 study variables depending on whether the decisions are made by one or two students 


\begin{tabular}{|l|c|}
\cline { 2 - 2 } \multicolumn{1}{l|}{} & Factor 1 \\
\hline TVA & 19353 \\
& $(0.000)$ \\
\hline Average stock & 3610.5 \\
& $(0.000)$ \\
\hline Average backlog & 5910 \\
& $(0.000)$ \\
\hline
\end{tabular}

Table 4. Mann-Whitney U Test for differences between the two levels of the factor ( $p$-value in parentheses) 


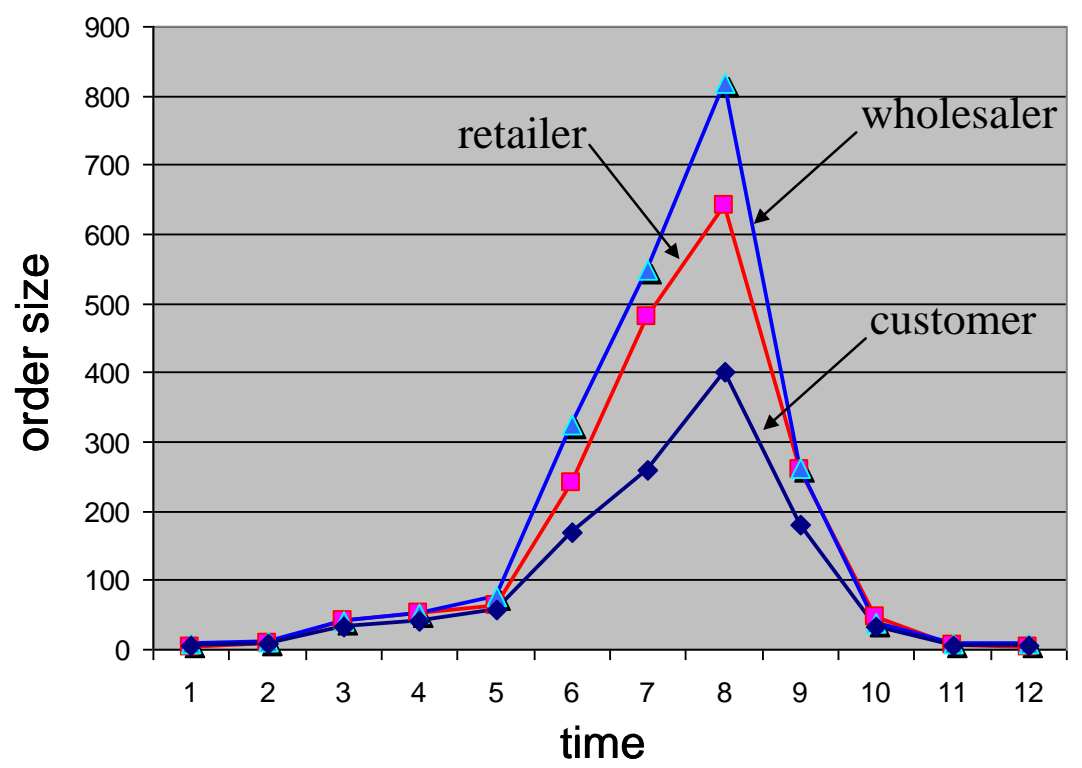

Figure 1. Amplification of order size due to the bullwhip effect 


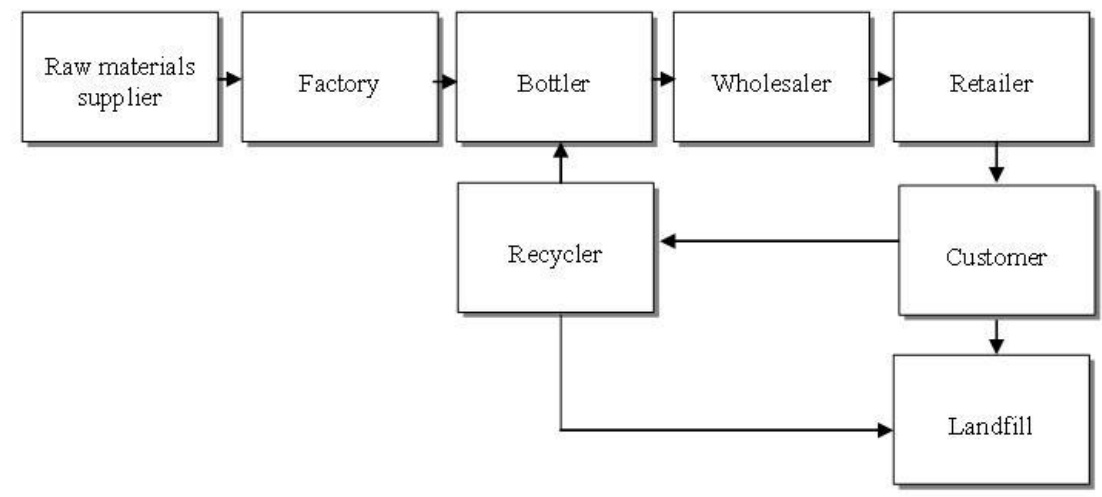

Figure 2. Supply chain actors in the Cider Game 


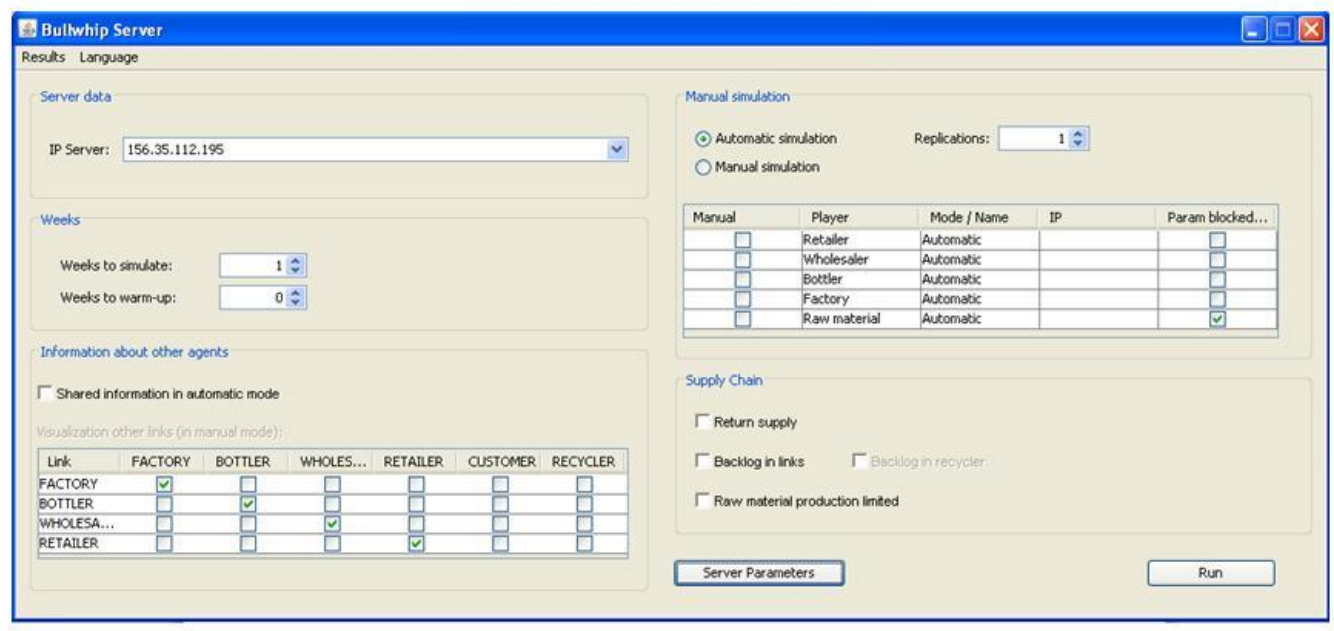

Figure 3. Main screen of the Cider Game 


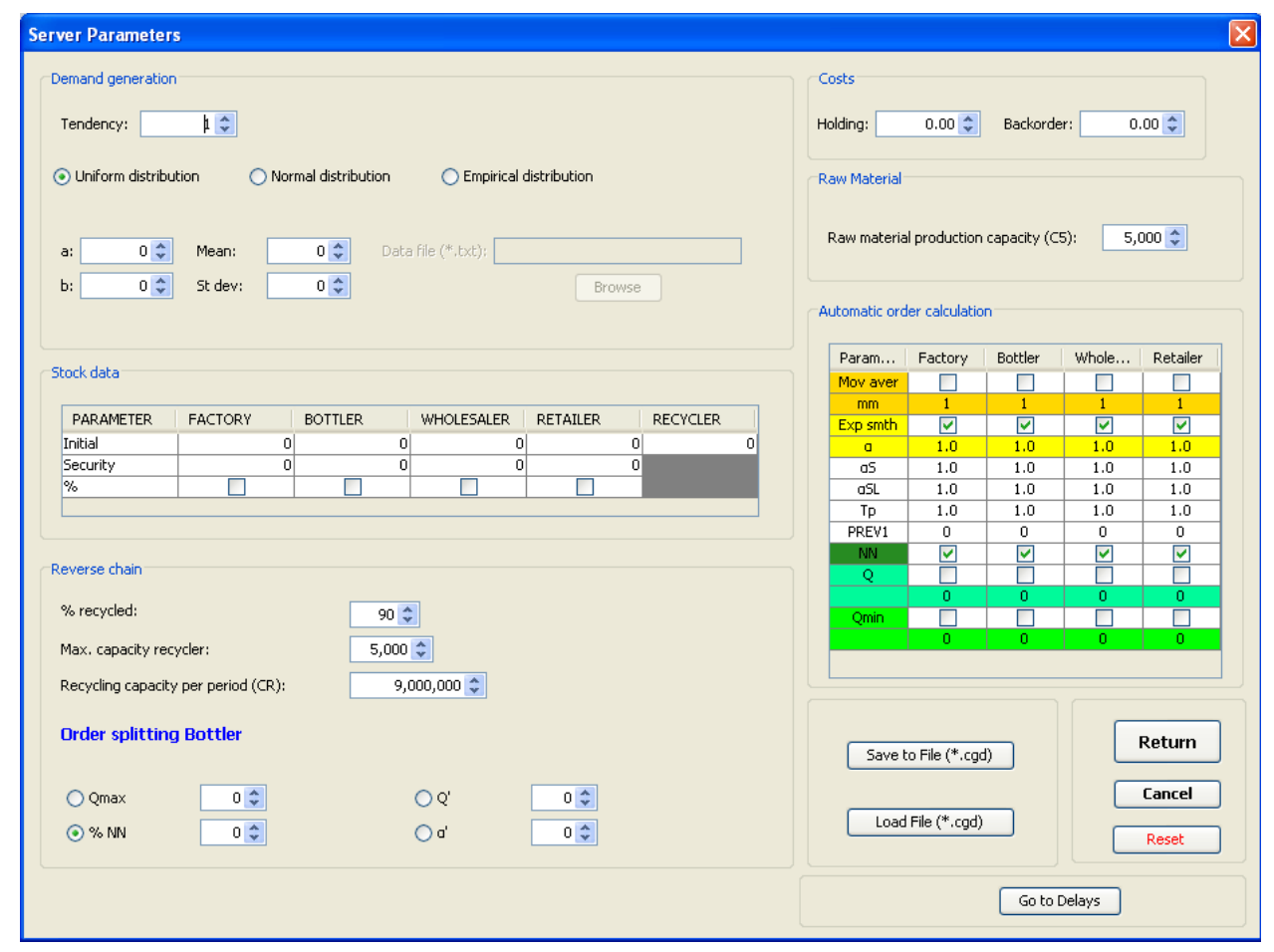

Figure 4. Parameters screen of the Cider Game 


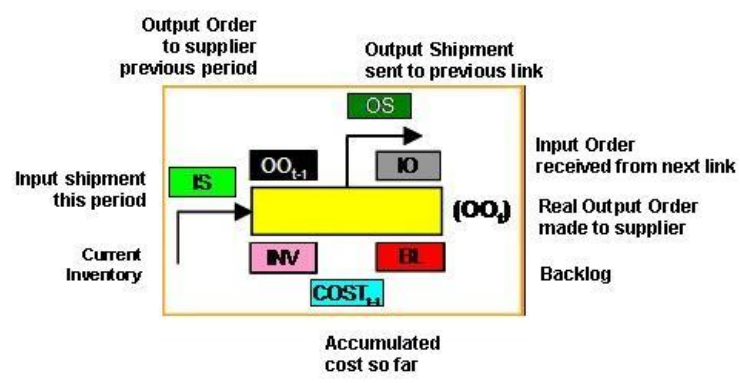

Figure 5. Information available on the simulation screen to the decision maker regarding the data for the link 


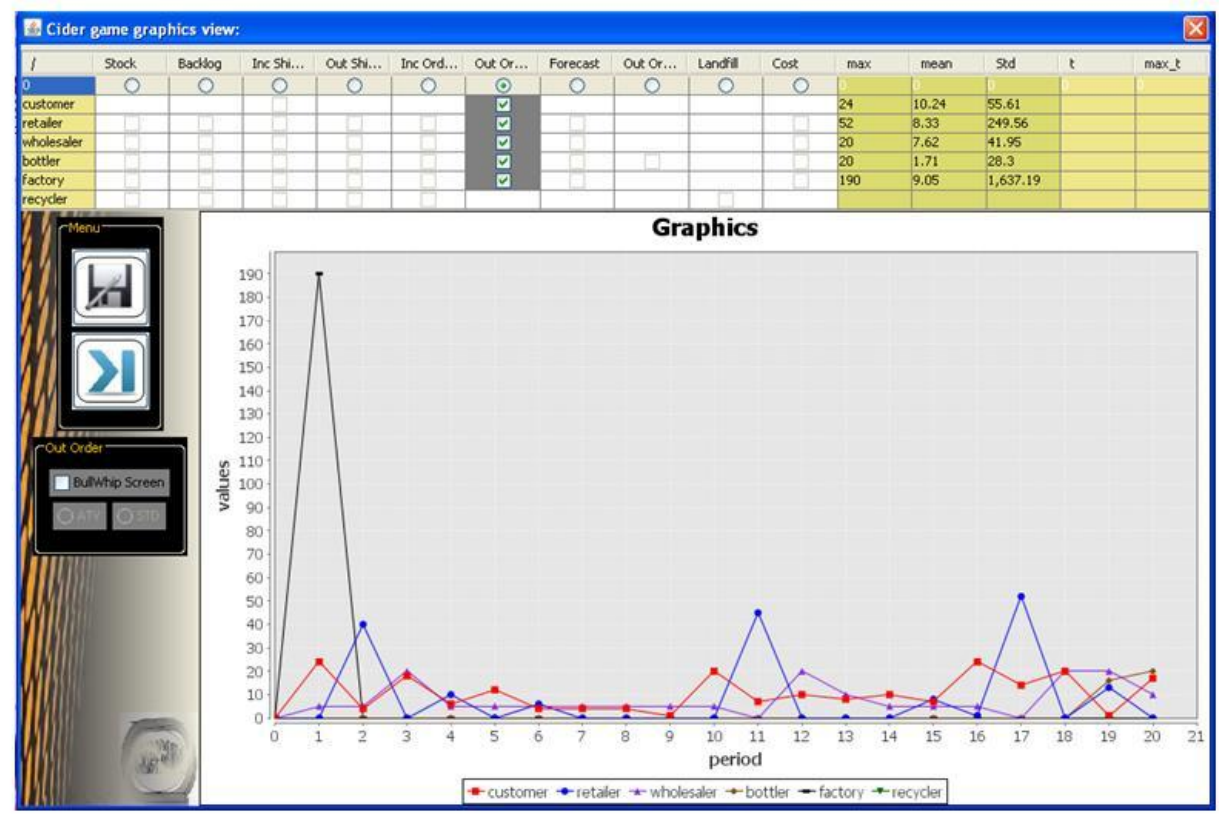

Figure 6: Results screen 



Figure 7: Boxplots of the three variables analyzed 